\title{
An overview of particulate matter emissions from modern light duty vehicles
}

This paper presents a comparison of particle mass and number emissions from different types of vehicles with sparkignition (SI) engines, with MPI and DI fuelling systems and compression-ignition (CI) engines with DI fuelling system with/without Diesel particles filters (DPF). The methodology of particulate mass and particle number emissions measurement with a full flow dilution tunnel for LDD engines and particulate sampling system is described. The results of measurements performed according to Euro 5/Euro 6 requirements for PC and LDV vehicles are presented, as performed on the chassis dynamometer in the Exhaust Emission Laboratory of BOSMAL Automotive Research and Development Institute (in Bielsko-Biala), Poland.

Key words: engine, particulate matter emission, vehicle

\section{O emisji cząstek stałych z nowoczesnych samochodowych silników spalinowych}

$W$ artykule przedstawiono porównanie emisji czastek statych (masy i liczby) z różnych samochodów z silnikami o zaptonie iskrowym (ZI) z wielopunktowym (MPI) i bezposrednim wtryskiem paliwa (DI), jak również z silnikami o zapłonie samoczynnym (ZS) z bezpośrednim wtryskiem paliwa oraz bez/z filtrem cząstek stałych (DPF). Opisano metodyke pomiaru masy i liczby cząstek stałych z wykorzystaniem petnoprzepływowego tunelu rozcieńczajacego dla samochodów z silnikami diesla i uktadu pobierania próbki spalin. W artykule przedstawiono wyniki pomiarów wykonanych na hamowni podwoziowej w Laboratorium Badania Emisji Spalin w Instytucie Badań i Rozwoju Motoryzacji BOSMAL, zgodnie z wymaganiami przepisów Euro 5/Euro 6 dla samochodów osobowych i lekkich samochodów użytkowych.

Słowa kluczowe: silnik, emisja cząstek stałych, pojazd

\section{Introduction}

Internal combustion engines (ICE) have been, are and will be the main solution for transportation for the foreseeable future, however, the ICE concept has certain key existential challenges to overcome $[1,2]$. Concern over the impact of vehicles on air quality remains high. Emissions of particulate matter are coming under increasing scrutiny as a form of pollution with wide-ranging negative impacts ranging from asthma to climate forcing. While the study of particles in vehicular exhaust has traditionally focused on mass-based quantification of emissions from compression ignition engines, there is now a growing awareness that other engine types (direct injection, port fuel injection) and other metrics and quantification methods (particle number, particle size distribution, particle surface area) are all worthy areas of investigation. In comparison to gaseous emissions, particle emissions still present multiple open questions and large domains of investigation [1, 3-5]. There are also considerable practical difficulties involved in investigating solid nanoparticle emissions from engines. Despite this, modern aftertreatment systems for reducing emissions of particulate matter have proven effective, although there remains much room for improvement.

As a consequence of more stringent exhaust emissions regulations in the USA, Europe, Japan and other industrialised countries, an effort to determine the cause of emissions and the development of new technologies for the reduction of emission levels from internal combustion engines have become a matter of prime importance. Compression ignition
(CI) engines have become an increasingly common feature of light-duty vehicles over the past few decades and engines with direct injection of petrol are used to power vehicles more and more frequently. Hence, the main problem to be solved is emission of particulate matter and nitrogen oxides.

Particulate matter emissions regulations are tightening in Europe and the US due to the environmental and health effects attributed to these emissions. The progress of the European emission regulation in limiting particle mass (PM) and number (PN) is shown in Fig. 1. Passenger cars (PC) and light commercial vehicles (LCV) are one of the most important sources of particle emissions, and their mass based PM emissions have been restricted in the EU since 1992. From the Euro 1 standard to the Euro 5 standard, the gravimetric PM limit was reduced $>95 \%$, to a point where accurate quantification became difficult, as the legislative limit approached the detection limit for the specified method. Toxicological studies have revealed that health effects are more closely related to particle number and surface area than mass. As a result of these two factors, a particle number limit was introduced in Euro 5b legislation [6] for CI engines. This emissions limit represents a significant departure from previous requirements, as the measurement technique is fundamentally different from the methods employed to quantify gaseous and PM mass-based emissions.

In addition to legislative requirements, particle counting systems are essential pieces of equipment for assessing the performance of PM aftertreatment systems (Diesel particulate filters, DPFs) for research and development work, 


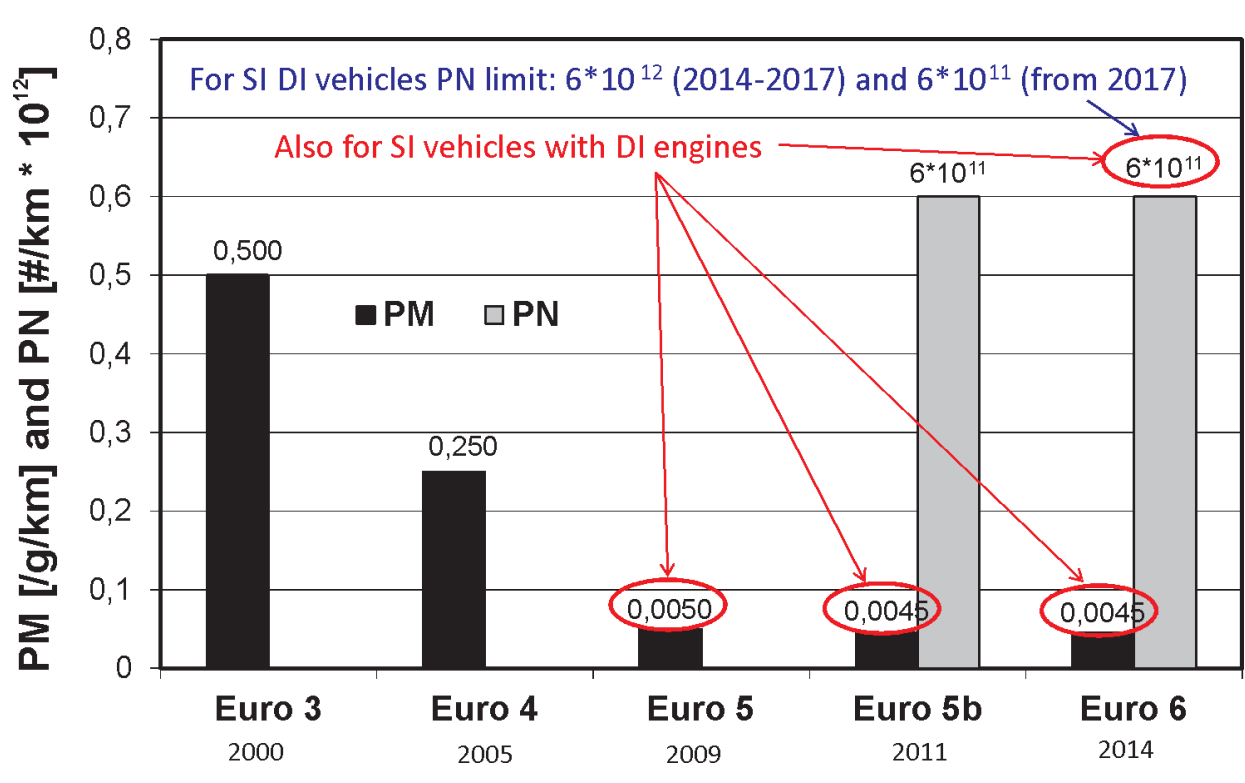

Fig. 1. PM and PN emission limits for passenger cars with CI engines (and for PC cars with SI DI engines) in EU countries

as the gravimetric PM technique is insufficiently sensitive to distinguish between DPF-filtered PM emissions in most cases [7]. The gravimetric PM limit and the PN limit are not equivalent [8], the PN limit being considerably more strin- gent, thereby making particle counting the critical research metric for CI engines and aftertreatment systems.

Gravimetric and numberbased emissions results are powerful tools for investigating engines, fuels, aftertreatment systems, particularly (but not exclusively) for Diesel engines and fuels and direct injection petrol engines. PM and PN results can be used to compare fuels [9-12], both in terms of legislative emissions limits, as well as meritocratically, whereby a direct comparison is made between different fuels or fuel blends. Interest in biofuels is increasing and since such fuels generally differ chemically and physically from fossil fuels,

PM and PN measurements form an important part of the armoury of tests that can be used to assess the environmental performance of biofuels and biofuel blends. It is tempting

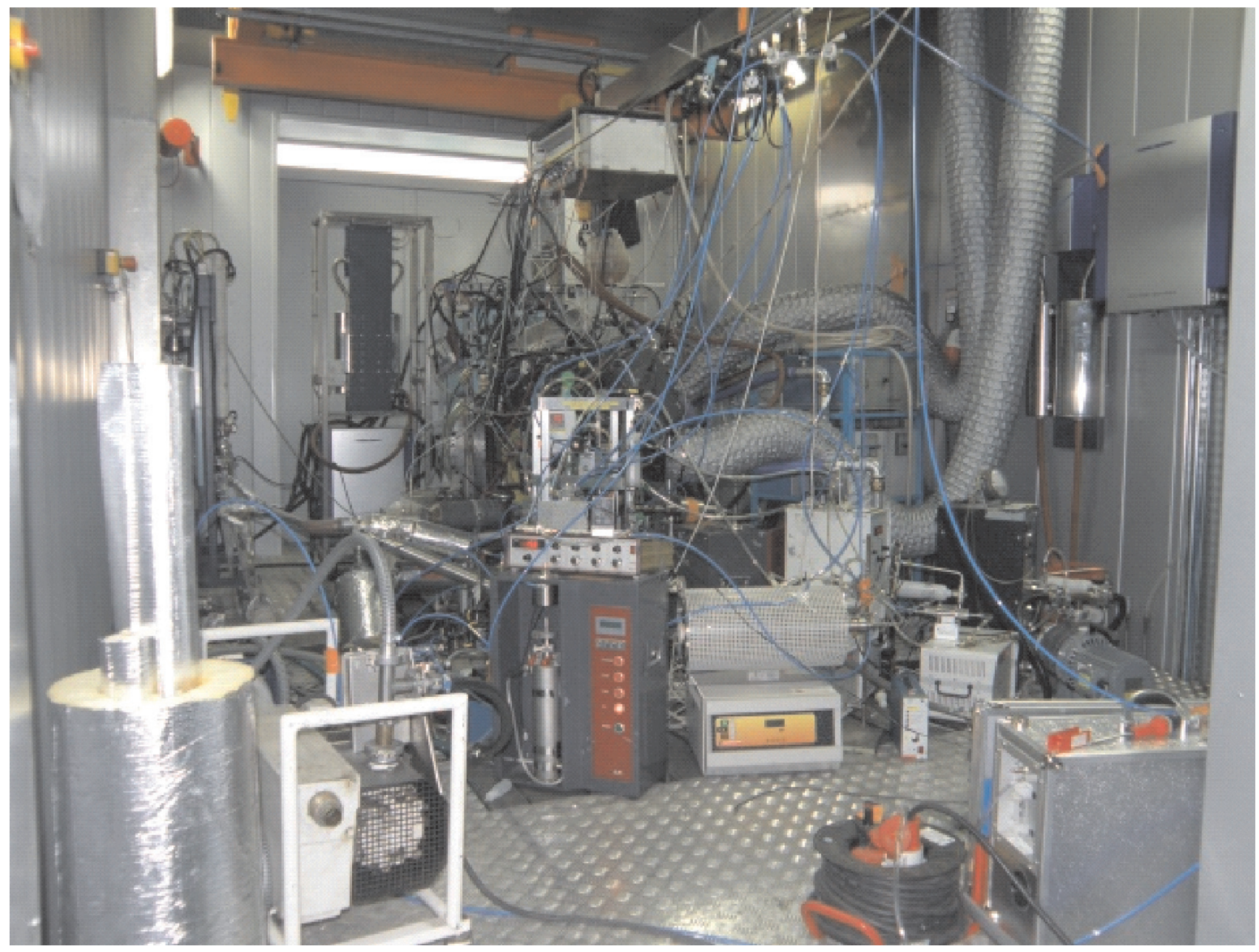

Fig. 2. One of BOSMAL's engine test cells with various devices to measure PM, PN and particle size distribution from IC engines installed 


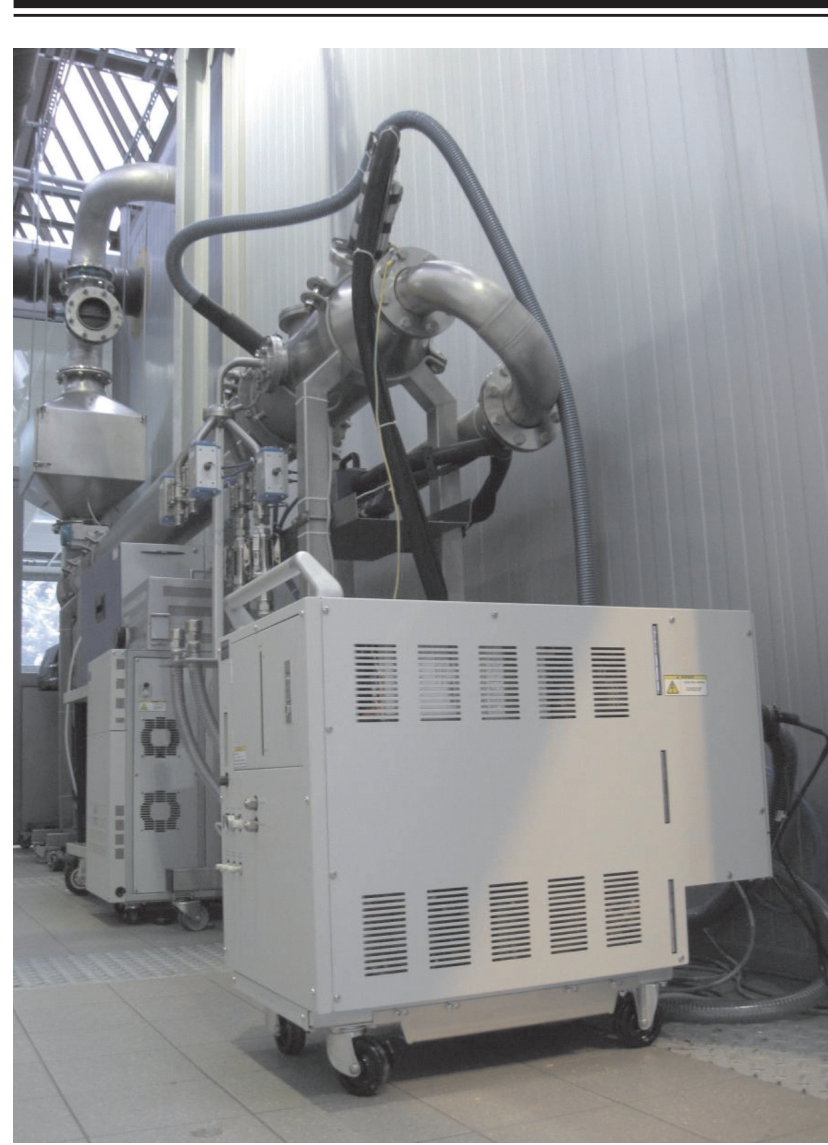

Fig. 3. Dilution tunnel (looking upstream) and HORIBA 2000-SPCS PN counter (foreground)

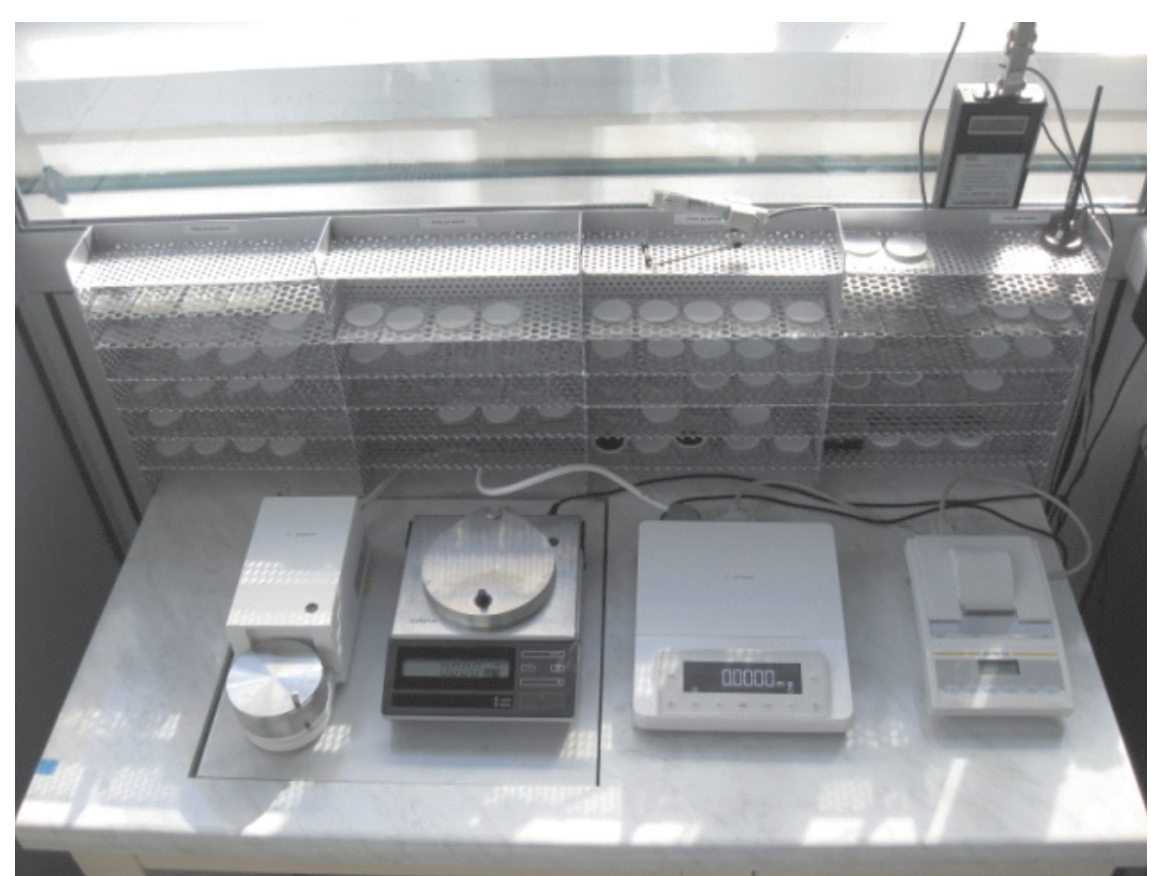

Fig. 4. Sartorious M5P-000V001 and MSE2.7S balances

to compare PM and PN, and thereby derive characteristics such as particle mass and even mean diameter. However, closer examination of the sampling conditions and measurement techniques reveals that the two methods measure

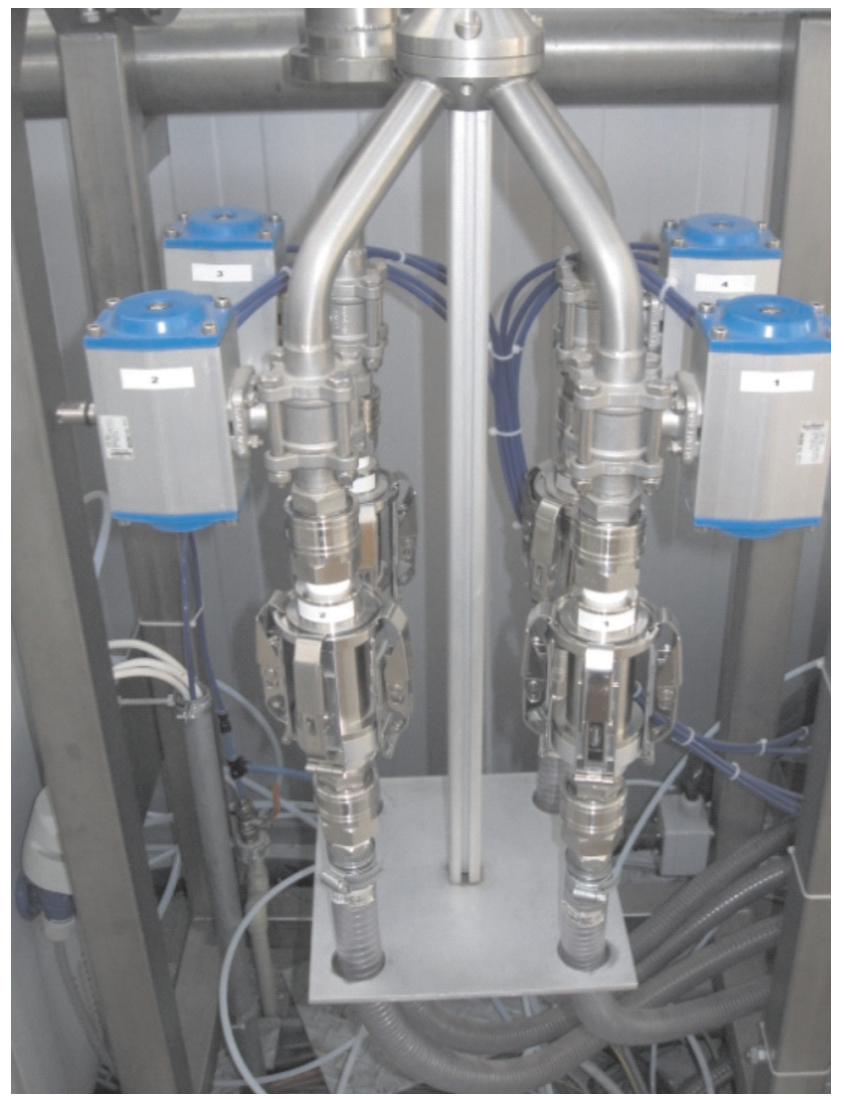

Fig. 5. Particulate sampling system for PM measurements

quite different things and therefore PM and PN cannot be directly correlated. However, with these caveats in mind, the two metrics can be compared. Where PM is sufficiently high (for some Diesel engines and direct injection petrol engines), a linear trend may be observed. However, this trend does not apply in all cases. Modern Diesel engines featuring DPF systems are easily able to meet the PM limit; the margin by which their PN emissions lie under the limit varies by orders of magnitude.

Particulates emitted in Diesel exhaust is a complex mixture of carbonaceous soot, unburned fuel and lubricating oil, and perhaps the products of fuel pyrolysis reactions. An example of a complex set-up to measure PM, $\mathrm{PN}$ and size distribution is presented in Fig. 2. Particulate matter can be both solid and liquid; typically PM includes four fractions of Diesel particulates: (1) solid soot, (2) SOF (soluble organic fraction; heavy hydrocarbons), (3) sulphur compounds and (4) ash. For modern engines, sulphur content is one of the fuel properties which has the greatest influence on particu- 
Table 1. Vehicles used in tests

\begin{tabular}{|c|c|c|c|c|}
\hline Vehicle type & Engine type & Fuel used & Swept volume $\left[\mathrm{dm}^{3}\right]$ & Emission level \\
\hline $\mathrm{A}$ & SI MPI & petrol & 1.2 & Euro 5 \\
\hline \multirow{2}{*}{$\mathrm{B}$} & \multirow{2}{*}{ SI MPI } & petrol & 1.4 & Euro 5 \\
\cline { 2 - 4 } & & CNG & 1.4 & Euro 5 \\
\hline $\mathrm{C}$ & SI DI & petrol & 1.8 & Euro 5 \\
\hline $\mathrm{D}$ & SI DI & petrol & 1.9 & Euro 4 \\
\hline $\mathrm{E}$ & CI DI & Diesel & 1.9 & Euro 4 \\
\hline $\mathrm{F}$ & CI DI & Diesel & 1.6 & Euro 5 \\
\hline $\mathrm{G}$ & CI DI & Diesel & 1.3 & Euro 5 \\
\hline $\mathrm{H}$ & CI DI & Diesel & \\
\hline
\end{tabular}

lates. Particulate emissions in Diesel exhaust are a function of a number of parameters, including: engine type, engine operating conditions, and fuel and lubricant oil composition. The size distribution of submicron Diesel exhaust particles

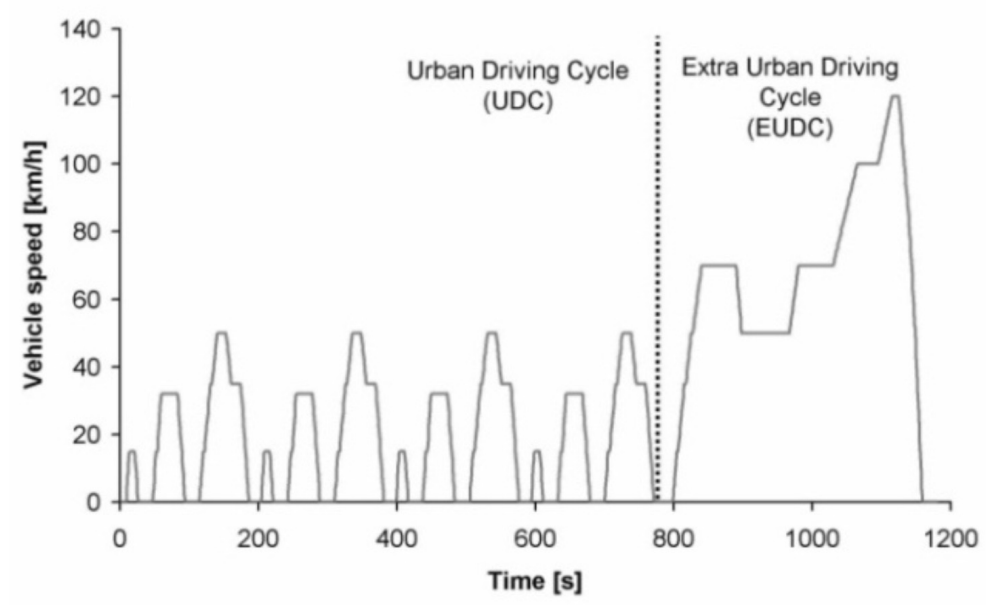

Fig. 6. The New European Driving Cycle (NEDC) can typically be divided into two separate modes called the accumulation mode (AM) and the nucleation mode (NM). The accumulation mode consists of solid agglomerated soot particles which can bear volatile or semivolatile components (e.g. sulphur compounds, water, hydrocarbons) on their surfaces. Nucleation mode particles are commonly reported to consist of water, sulphuric acid and hydrocarbons. Several studies have indicated that nucleation mode particles are semivolatile and that formation of the particles occurs when the exhaust gas is cooled and diluted in the atmosphere [13-15].

\section{Test methodology used during PM, PN and size distribution measuring}

A wide variety of tests have been carried out at BOSMAL's Emission Testing Laboratory (see [16]). A CVS-CFV sampling system together with a full-flow dilution tunnel (Horiba DLT-7020) (Fig. 3), a particulate sampling system (Horiba DLS-7100E) (Fig. 5), a particle number counting system (Horiba MEXA-2000SPCS) (Fig. 3) and a Sartorius microbalance (Fig. 4) have been used to measure exhaust particulate mass and number emissions from a range of vehicle and engine types.

Quantification of particle numbers shows better repeatability than mass based measurements at very low emission levels. The operating and quantification principal of a particle number counting system is described below. A size-selective sample is taken from the dilution tunnel, heated and diluted, treated at high temperature to evaporate volatiles (non-solid phase particles), further diluted and cooled, and then drawn into the condensation particle counter unit. Here the sample is dosed with a small quantity of

Fig. 7. PM emissions over the NEDC for different vehicles with SI and CI engine 
butanol, which condenses onto the particles present to increase their size and ensure detection. A closely controlled volume of the sample is passed through a laser beam. The resulting interruption of the laser beam is detected using a series of lenses and a photometer, which generates a signal indicating particle detection.

In addition to testing activities on CI engines, as required by Euro 5b legislation, the PN counter has also recently been used to measure particle number emissions from SI engines operating on various fuel types $[8,9]$, and to investigate emissions from DI SI engines (in connection with - and anticipation of - the upcoming PN limits for this engine type).

In one such study, a series of emissions tests were performed on eight vehicles - one bi fuel vehicle, one vehicle equipped with a standard petrol engine, two vehicles with DI petrol engines, two Diesel vehicles (Euro 4) with unit injectors, and two Diesel vehicles (Euro 5) with Common Rail DI engines with Diesel particulate filters (DPF). Selected key properties of the test vehicles are shown in Table 1.

The New European Driving Cycle (NEDC) was used to test all vehicles (Fig. 6).

\section{Analysis of particulate emissions measurement results}

A summary of the chassis dynamometer test results for all test vehicles using Diesel, petrol or CNG fuels are shown in Figs 7-13. These figures show observed trends for particulate exhaust emissions in different phases of the NEDC cycle for different fuelling systems and different fuels. A comparison of PM exhaust emissions (Figs. 7 and 8) measured in the NEDC cycle shows that these emissions are very low for gasoline engines with multi-point injection systems fuelled with petrol as well as with $\mathrm{CNG}$ and for Diesel vehicles with a DPF; they are several times higher for SI engines with directinjection fuelling systems and much higher for Diesel vehicles without a DPF.

In the case of PN emissions (Figs. 9-11) it is immediately apparent that these emissions are the lowest for Diesel vehicles with a DPF (even lower than for the vehicle fuelled with $\mathrm{CNG}$ ); they are reasonably high for the SI engines with direct-injection fuelling systems (three times higher than the proposed Euro 6 limit for SI vehicles with DI engines) and very high for Diesel vehicles without a DPF. The highest PN emissions were measured at the beginning of the test due to the cold start effect (Fig. 11) and during each acceleration to speeds above $20 \mathrm{~km} / \mathrm{h}$.

The size distribution of particles emitted over the NEDC for the petrol vehicle with DI engine and for the Diesel

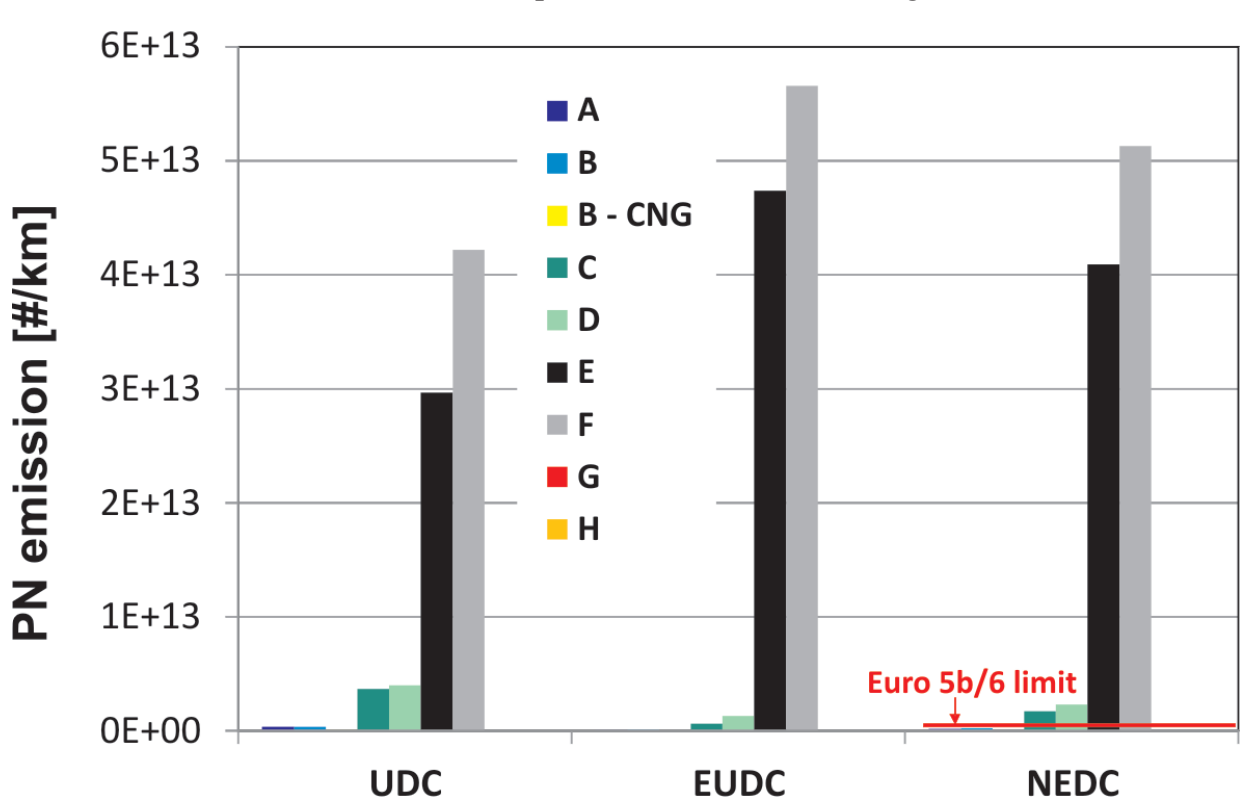

Fig. 9. PN emissions over the NEDC for different vehicles with SI and CI engine 


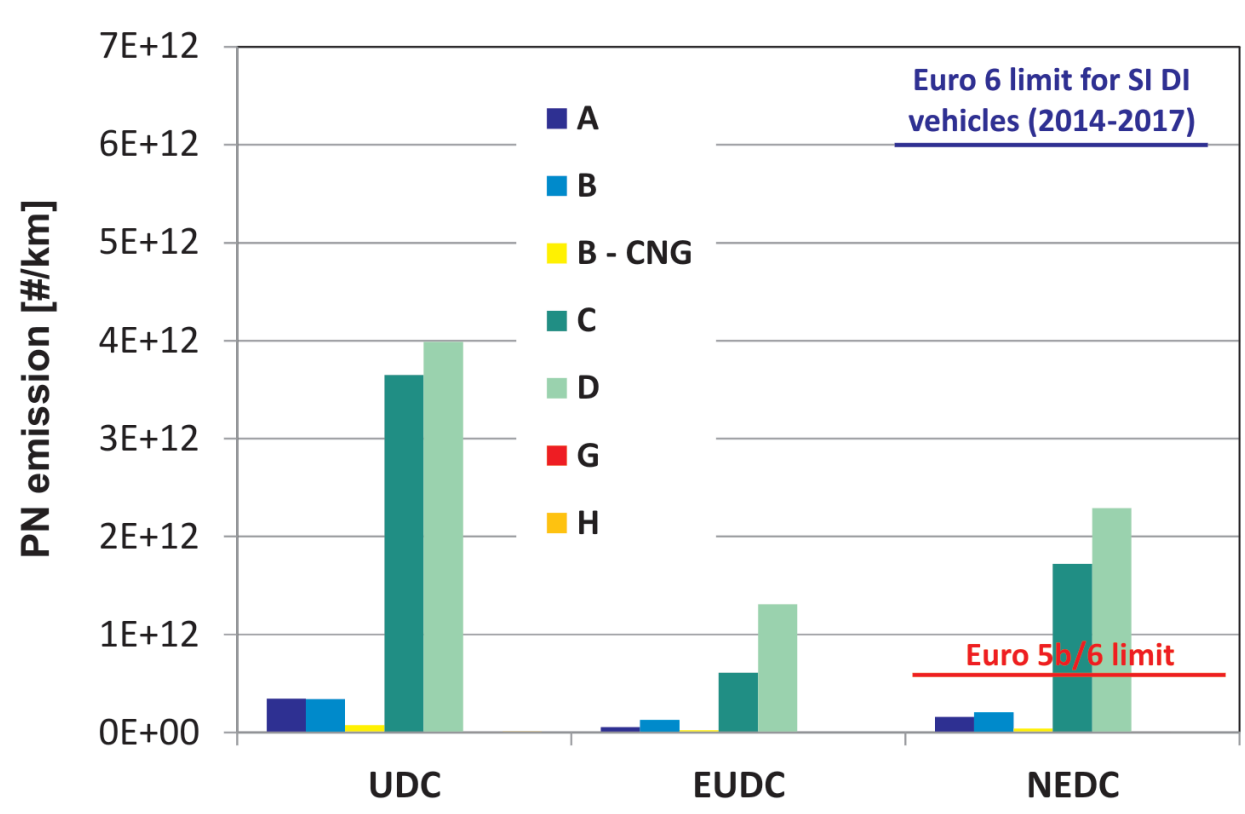

Fig. 10. PN emissions over the NEDC for different Euro 5 vehicles with SI and CI engine

A range of vehicles, featuring MPI SI, DI SI and CI engines were tested over the NEDC for comparison of PM and $\mathrm{PN}$ emissions. The results of this research indicated:

- Particle emissions are detectable from all engine types.

- The legislative PM and PN methodologies are generally effective tools for quantifying particle emissions.

- The fuel delivery strategy and the physicochemical characteristics of the fuel influence PM an PN to varying degrees.

- Cold start PM and PN emissions are significant and depend strongly on the ambient temperature.

- PM emissions over the entire NEDC were the lowest for the vehicle fuelled with CNG. For

vehicle with a DPF are shown in Figs 12 and 13. This is an additional measurement, not required by the legislation, but which provides very interesting data on the size of particles in the exhaust.

In the aforementioned research programme, a TSI Particle Sizer Spectrometer 3090 was used to measure the size distribution of particles. The measuring range of the TSI Particle Sizer Spectrometer 3090 is 5.6-560 nm.

The majority of particles for vehicle D (Fig. 11) and vehicle $\mathrm{G}$ had diameters of between 5 and $200 \mathrm{~nm}$, and they are not measured during the legislative particulate mass measurement (membrane filters used for PM measurement filter out $99 \%$ of particles of diameter $\geq 300 \mathrm{~nm}$ ). Also, the PN counter doesn't measure all particles (the measuring range of this device is $23-2500 \mathrm{~nm}$ ). This shows how important it is to use a method of measurement which allows the quantification of nanoparticles of a wider size range.

\section{Conclusions and summary}

Particle emissions from internal combustion engines are on ongoing problem and a research priority. BOSMAL's well-equipped laboratory is an example of the type of highend testing facility which is required for research on this topic. Sample results presented in this paper are summarized below.

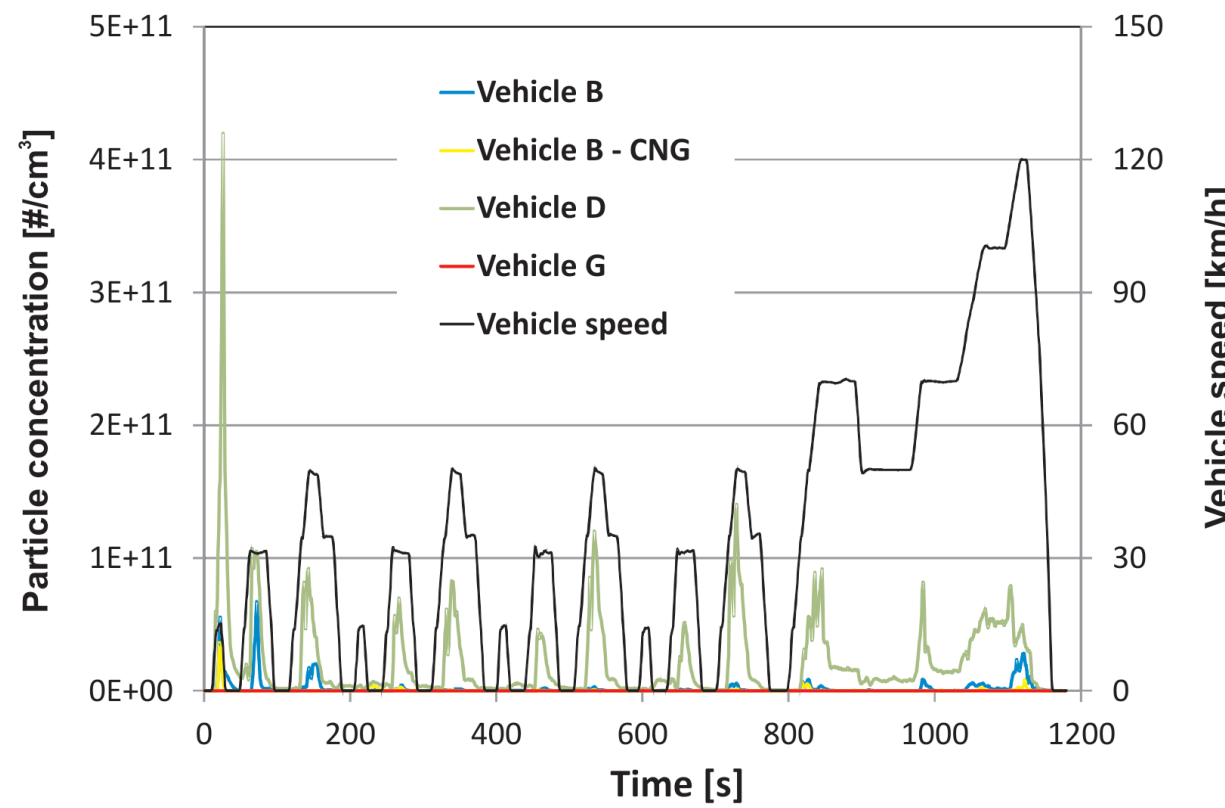

Fig. 11. Second-by-second particle concentration over the NEDC for different Euro 5 vehicles 
hicles with SI MPI engines, 447-595 times higher for the vehicles with SI DI engines, and more than 10 000 times higher than for the vehicles with CI engines without a DPF; all in comparison to the vehicles with $\mathrm{CI}$ engines equipped with a DPF.

Modern Diesel engines featuring DPF systems are easily able to meet the PM limit; the margin by which their PN emissions lie under the limit varies by orders of magnitude. Research performed by BOSMAL has shown that while mass emissions from modern direct injection engines are reasonably low (generally below $5 \mathrm{mg} / \mathrm{km}$, at least over the NEDC), PN emissions are very high. Thus, the upcoming PN limit for this engine type will force the use of some form of aftertreatment system (either a GPF or a continuously regenerating POC). Emissions limits are unlikely to remain static and further reductions in the limits are anticipated in the coming decades. Additionally, the specified methodologies for measuring PM and PN may well change. Furthermore, particle emissions limits may eventually be introduced for all engine types, regardless of injection strategy or fuel type.

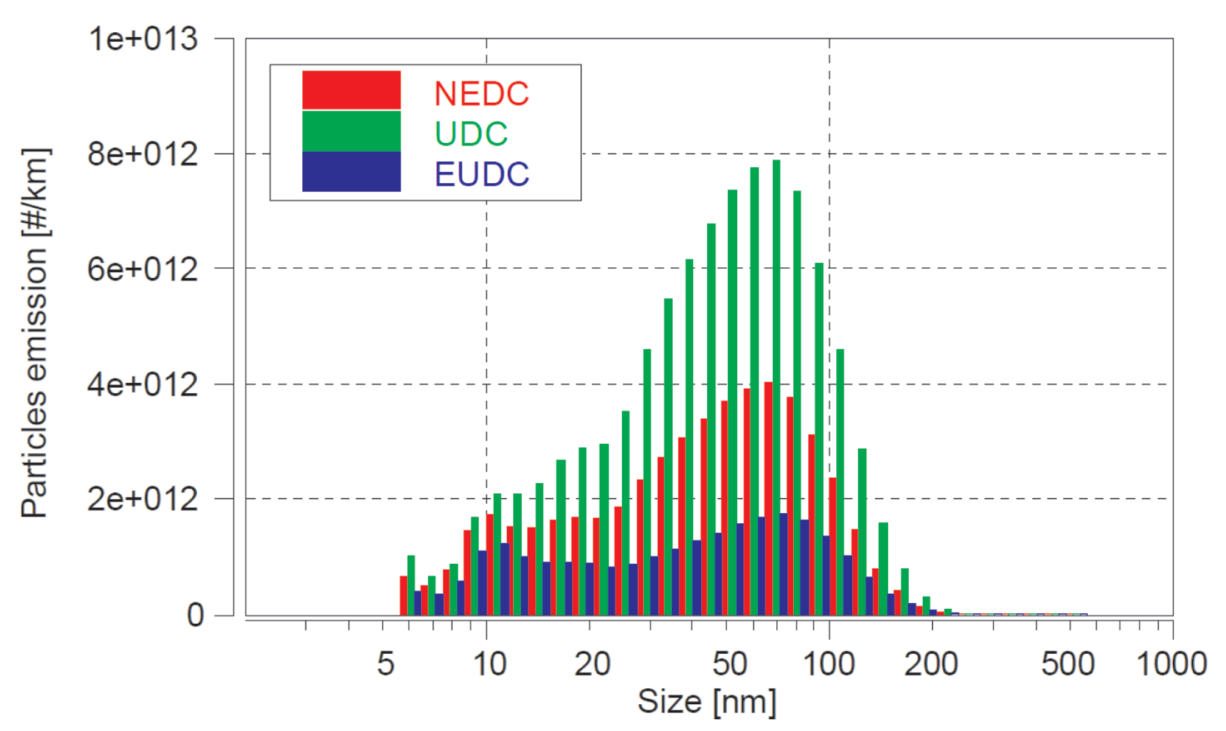

Fig. 12. Size distribution of particles over the NEDC for vehicle D

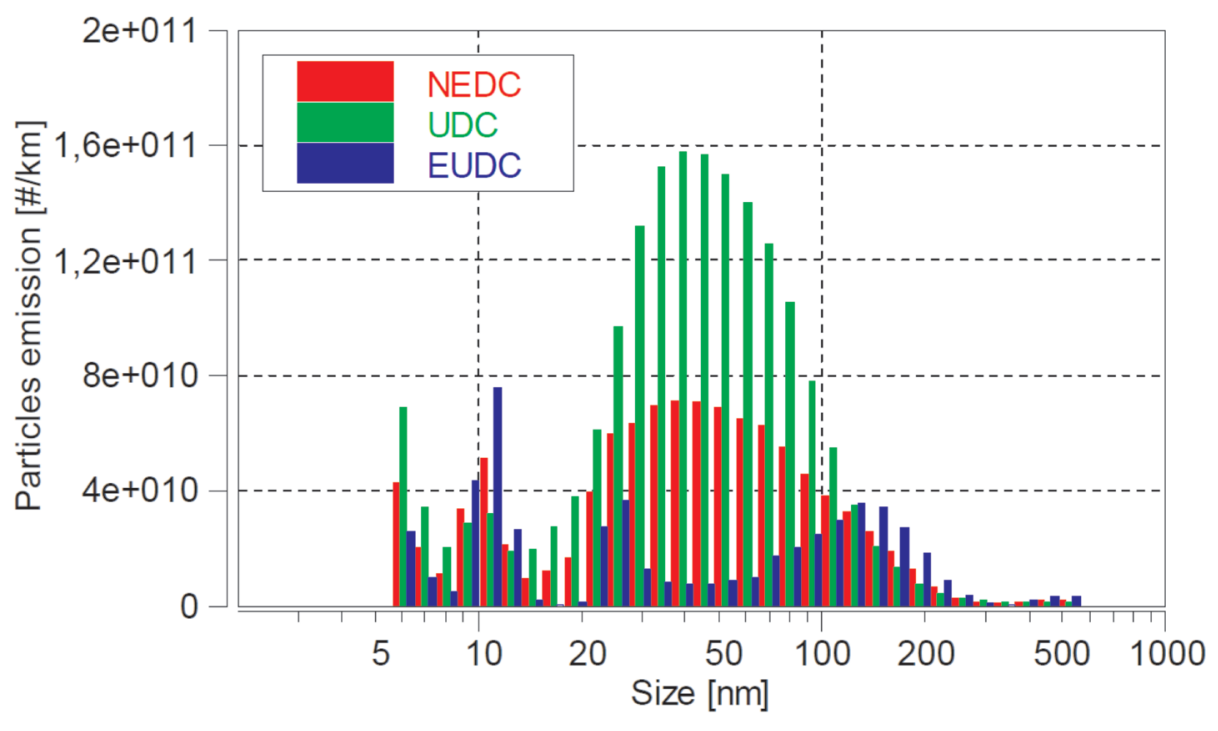

Fig. 13. Size distribution of particles over the NEDC for vehicle G

\section{Nomenclature/Skróty i oznaczenia}

CI compressed ignition/silnik o zapłonie samoczynnym

CNG Compressed Natural Gas/sprężony gaz ziemny

DI direct injection/wtrysk bezposredni

DPF Diesel particulate filter/filtr czastek statych

EU European Union/Unia Europejska

EUDC extra urban driving cycle/pozamiejski cykl jezdny

GPF gasoline particulate filter/filtr czastek statych dla samochodów z silnikiem ZI DI

ICE internal combustion engine/silnik spalinowy wewnętrznego spalania

LDD light duty diesel/silnik ZS dla pojazdu LDV

LDV light duty vehicle/lekki pojazd użtkowy

MPI multi point injection/wtrysk wielopunktowy
NEDC New European Driving Cycle/nowy europejski cykl jezdny

PC passenger car/samochód osobowy

PM particulate matter/cząstki state

PN particle number/liczba czastek statych

POC particulate oxidation catalyst/reaktor katalityczny utleniajacy cząstki state

SI spark ignition/silnik o zapłonie iskrowym

SOF soluble organic fraction/ciekła frakcja organiczna

UDC urban driving cycle/miejski cykl jezdny

ZI silnik o zaptonie iskrowym

ZS silnik o zapłonie iskrowym 


\section{Bibliography/Literatura}

[1] Bielaczyc P., Czerwinski J., Woodburn J.: Current trends in measurement and control of particle emissions from engines (perspectives from the 1st Workshop on Particulate Matter Emissions from Engine and Automobile Sources. 2 July 2012, Bielsko-Biala, Poland). Combustion Engines 3/2012 (150), pp. 89-98.

[2] Johnson T.: Vehicular Emissions in Review. SAE Int. Journal of Engines. 6(2):2013, doi:10.4271/2013-01-0538.

[3] Kittelson D., et al.: Issues associated with solid particulate measurement. Workshop Proceedings form 1st Workshop on Particulate Matter Emissions from Engine and Automobile Sources on CDROM, BOSMAL Automotive R\&D Institute, 2nd July 2012, Bielsko-Biala, Poland, ISBN 978-83-9313833-3, Combustion Engines 3/2012 (150).

[4] Bielaczyc P. (editor): Particulate Matter Emissions from Engine and Automobile Sources. Workshop Proceedings form 1st Workshop on Particulate Matter Emissions from Engine and Automobile Sources on CDROM, BOSMAL Automotive R\&D Institute, 2nd July 2012, Bielsko-Biala, Poland, ISBN 978-83-931383-3-3. Combustion Engines $3 / 2012$ (150).

[5] Bielaczyc P., Merkisz J., Pajdowski P., Woodburn J.: Correlation between two commercially available PMP-compliant particle number counting systems. Combustion Engines 2/2012 (149) pp 10-21, paper PTNSS-2012-SS2-102.

[6] Commission Regulation (EC) No 692/2008 of 18 July 2008 implementing and amending Regulation (EC) No $715 / 2007$ of the European Parliament and of the Council on type-approval of motor vehicles with respect to emissions from light passenger and commercial vehicles (Euro 5 and Euro 6) and on access to vehicle repair and maintenance information. Official Journal of the European Union, L199, 1-136, 28.7.2008.

[7] De Filippo A.: Particle Size and Number Emissions from Modern Light-Duty Diesel Vehicles. SAE Technical Paper 2011-01-0632, doi:10.4271/2011-01-0632.

[8] Bielaczyc P., Pajdowski P., Szczotka A., Woodburn J.: Particle mass and number emissions from a range of European lightduty vehicles. Workshop Proceedings of the 1st Workshop on Particulate Matter Emissions "Particulate Matter Emissions from Engine and Automobile Sources" 2 July 2012 BielskoBiala, Poland, ISBN 978-83-931383-3-3. Combustion Engines 3/2012 (150)

[9] Bielaczyc P., Klimkiewicz D., Pajdowski P., Szczotka A., Woodburn J.: An examination of the effect of ethanol-gasoline blends' physicochemical properties on emissions from a lightduty spark ignition engine. Fuel Processing Technology, 107, 50-63 2012, doi:10.1016/j.fuproc.2012.07.030.

Piotr Bielaczyc, DEng. - head of the Engine Research Department, BOSMAL Automotive Research and Development Institute Ltd in Bielsko-Biała.

Dr inż. Piotr Bielaczyc - kierownik Zakładu Badań Silników, Instytut Badań i Rozwoju Motoryzacji BOSMAL Sp. z o.o., Bielsko-Biała.

e-mail: piotr.bielaczyc@bosmal.com.pl

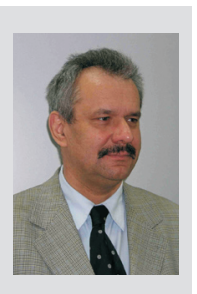

[10] Kozak M., Merkisz J., Bielaczyc P., Szczotka, A.: Environmental Performance of Diesel Fuels Containing Oxygenated Additive Packages. F2012-B01-045, F2012-A04-014, SAEChina and FISITA (eds.), Proceedings of the FISITA 2012 World Automotive Congress, Lecture Notes in Electrical Engineering 189, doi:10.1007/978-3-642-33841-0_52, Springer-Verlag Berlin Heidelberg 2013.

[11] Bielaczyc P., Woodburn J. and Szczotka A.: An Investigation into Cold Start Emissions from Compression Ignition Engines using EU Legislative Emissions Test Procedures. SAE Int. Journal Fuels Lubr. 6(2):2013, doi:10.4271/2013-01-1304. 2013 SAE World Congress, Detroit, USA.

[12] Bielaczyc P., Keskinen J., Dzida J., Sala R. et al.: Performance of Particle Oxidation Catalyst and Particle Formation Studies with Sulphur Containing Fuels. SAE Int. Journal Fuels Lubr. 5(2):2012, doi:10.4271/2012-01-0366. 2012 SAE World Automotive Congress, Detroit, USA.

[13] Bielaczyc P., Kozak M., Merkisz J.: Effects of Fuel Properties on Exhaust Emissions from the Latest Light-Duty DI Diesel Engine, JSAE 20030355, SAE Technical Paper 2003, 2003 01-1882, doi:10.4271/2003-01-1882.

[14] Filippo A., Maricq M.: Diesel Nucleation Mode Particles: Semi-volatile or Solid? Environmental Science and Technology 2008, 42, 7957-7962, doi:10.1021/es8010332.

[15] Uhrner U., von Löwis S., Vehkamäki H., Wehner B., Bräsel S., Hermann M., Stratmann F., Kulmala M., Wiedensohler A.: Dilution and aerosol dynamics within a diesel car exhaust plume-CFD simulations of on-road measurement conditions. Atmospheric Environment, 2007, 41, 7440-7461, doi:10.1016/j. atmosenv.2007.05.057.

[16] Bielaczyc P., Szczotka A., Pajdowski P., Woodburn J.: Development of automotive emissions testing equipment and test methods in response to legislative, technical and commercial requirements. Combustion Engines 1/2013 (152).

Andrzej Szczotka, DEng. - doctor in Engine Research Department at the BOSMAL Automotive Research \& Development Institute Ltd in Bielsko-Biała.

Dr inż. Andrzej Szczotka-adiunkt w Zaktadzie Badań Silników Instytut Badań i Rozwoju Motoryzacji BOSMAL Sp. z o.o., Bielsko-Biała.

e-mail: andrzej.szczotka@bosmal.com.pl

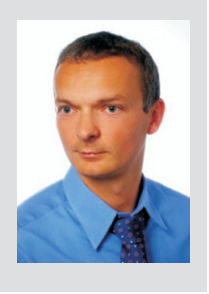

Joseph Woodburn, MSci. - researcher at the Engine Research Department, BOSMAL Automotive Research and Development Institute Ltd in Bielsko-Biała.

Mgr inż. Joseph Woodburn - inżynier ds. badań w Zaktadzie Badań Silników, Instytut Badań i Rozwoju Motoryzacji BOSMAL Sp. z o.o., Bielsko-Biała.

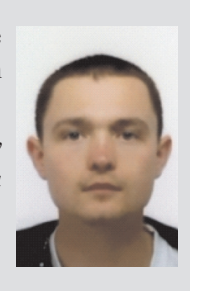

